\title{
Appraisal of Canal Irrigation Project: A Case Study of Eight Minors of Karchhana Distributary
}

\author{
Saad Asghar Moeeni ${ }^{1 *}$ and Sherif ${ }^{2}$ \\ ${ }^{1}$ Department of Civil Engineering, Research Scholar, India \\ ${ }^{2}$ Department of Civil Engineering, Jamia Millia Islamia,New Delh, India
}

Submission: June 10, 2017; Published: June 27, 2017

*Corresponding author: Saad Asghar Moeeni, Department of Civil Engineering, Research Scholar, Jamia Millia Islamia,New Delhii, India, Tel: 7536067643; Email: smoeeni@gmail.com

\begin{abstract}
In India irrigation planning was made on the aspects and agronomical aspects have been neglected in the past. Hence water supply through most of the canals is inadequate and highly varying to meet the supply requirement of their command assessment of different components of the water released from the canal off takes of very important to ensure optimum water utilisation in the canal command. This project report presents a case study to investigate whether the water supply by the different minors of sufficient to meet the actual supply requirement and to suggest suitable solution towards efficient utilization of water resources for potential crop production. The study was carried out for eight minor of karchhana distributary.

Investigation reveals that there is a controversy between water users and canal authorities. Water users complained the tail end users never received irrigation water while authorities claimed that they supplied sufficient water to meet the irrigation water demand. The information gathered after the intensive survey in the command area using models recommended by FAO. Potential evapo-tranpiration was computed by modified penman equation (FAO 1997). Crop water requirements, project supply requirements and irrigation schedules were computed. Deficient and excess water supply during the crop growing season was identified. Results revealed that the water supplied by each were highly insufficient to meet the supply requirements for their respective command areas.
\end{abstract}

Keywords: Evapo-tranpiration; Canal command; Modified Penmen; Crop water requirements; FA0; Water user

\section{Introduction}

Water as such and also carry a large amount of nutrients, in a large measure for successful growth of crop, so water is an important natural resource for agriculture. Due to inadequate distribution of rainfall during growth span of crops, it becomes essential to apply additional water to the soil for irrigation. The available water resources in India are not sufficient to irrigate the cultivable area. Therefore efforts are needed to optimize the use of water for of irrigation and hence judicial use is strongly recommended. India is basically an agricultural country having $70 \%$ of its economically dependent on agriculture. Food security of a major concern in many parts of the world including the densely populated countries like India.

Immense pressure on infinite land and water resources of India can be gauged from the fact that it shares $2.45 \%$ geographical area and 4\% water resources of the world but supports $16 \%$ population and $18 \%$ livestock of the world. Sustainable agriculture production from these limited resources in order to meet the food requirement of ever increasing population of India is a challenge to researchers, planners and policy makers. Though operation and maintenance of existing irrigation systems and development of new irrigation projects both are important but the former of being preferred over the later due to low budget requirements. Hence, to achieve sustainable agriculture production resource use efficiency needs to be enhanced along with bringing additional area under irrigation.

Study to identify the constraints in water delivery from canal and develop performance indicators from the point of view of water users and canal managers in India reflects that there are multi-dimensional problems like technical, socio-economic, hydraulic, managerial, institutional and financial related to water release, allocation, distribution and utilisation in canal command and lack of frequent communication and dialogue among water users and canal managers. The major reported by the water users was mismatch/wide gap between water supply and demand leading to water stress conditions either due to 
excess or deficit availability and ultimately adversely affecting the crop [1].

\section{Materials and Methods}

\section{Project Identification}

The study was carried out for appraisal of the eight minors namely Majhgawan, Barguana, Banoury, Baitibajhiya, Baraouli Purwa, Tilakhwar and Kareha minors of karchhana Distributary. A detailed survey will be made to collect information about the physical condition of main canal and the minor canals, climatic conditions, soil type cultural practices, cropping pattern, water resources potential, marketing and storage facilities, socioeconomic condition of the farmers, educational standards and existence of water use associations. Detailed information about the length, width, discharge, time and duration of canal running, GCA as well as CCA of above mentioned distributaries and minors was obtained from the office of Executive Engineer, UP Irrigation Department, Govindpur, Allahabad. The climatic data which includes the maximum and minimum daily temperature, relative humidity, actual sunshine hours, wind velocity cloud amount and rainfall was obtained from Meteorological Department, SHIATS, and Allahabad [2].

\section{Cropping Intensity}

Although the project area has good availability of labor and marketing facilities, mainly rabi crops were grown which include wheat, gram and potato. During the kharif season only paddy was grown while during months of May and June, no major crop is grown $[3,4]$.

\section{Method of irrigation and Soil type}

The soil of the command area is clayey loam to sandy loam having good infiltration characteristics. The area is fairly levelled with some undulation at few places. The surface methods of irrigation are in practice.

\section{Crop Water Requirement}

The crop water requirement (ETcrop) for different crops grown in command area is calculated by the following method:

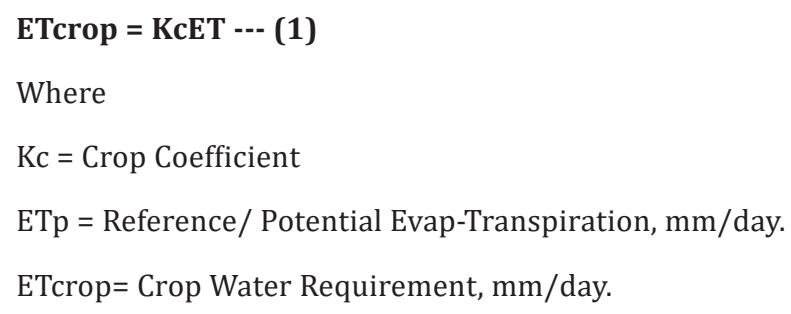

The modified Penman's Equation FAQ (1977) will be used to estimate the Refrences/Potential Evap-Transpiration (ETp). The details of the model are given below:

ET p $=$ C [W.Rn + (I-W).f (ea-ed) $]---(2)$

Where
ETp $=$ Reference $/$ Potential Evap-Transpiration, mm/day.

$\mathrm{W}=\mathrm{a}$ temperature and elevation related weighing factor.

$\mathrm{Rn}=$ net radiation in equivalent evaporation, $\mathrm{mm} /$ day .

$\mathrm{F}(\mathrm{u})=$ wind related function

ea-ed = differences between the saturation vapor pressure at mean air temperature and mean actual vapor pressure of the air, mbar

$\mathrm{C}=$ adjustment factor to compensate say and night weather

The components for the modified Penman's model were estimated as follows:

1. Actual vapor pressure was computed by the following formula:

Ed = eaxrmmean-100--- (3)

Where

R.Hp = relative humidity, \%.

(Obtained from Metrological Department)

$\mathrm{Ea}=$ saturation vapor pressure, mbar.

(Obtained from table FAO 1977)

Ed = actual vapor pressure, mbar.

2 . Wind speed at $2 \mathrm{~m}$ height was converted in respective $5 \mathrm{~m}$ height with the help of correction factor and $f(u)$ was calculated by the following formula:

$F(u)=0.27(1+u / 100--(4)$

Where

$\mathrm{U}=24 \mathrm{hrs}$ wind speed at $2 \mathrm{~m}$ height, $\mathrm{km} /$ day

3. Temperature related weighing factor $\mathrm{W}$ and $(1-\mathrm{W})$ were obtained from tables for respective mean air temperature (FAO 1997).

4. Net radiation $(\mathrm{Rn})$ was calculated with the help of the series of formulae (FAO 1997).

R = Rns-Rnl----- (5)

Where

$\mathrm{Rn}=$ net radiation in equivalent evaporation, $\mathrm{mm} /$ day .

Rns $=$ net short wave radiation, $\mathrm{mm} /$ day .

$\mathrm{Rnl}=$ net long wave radiation, $\mathrm{mm} /$ day .

Rs $=(0.25+0.5 n / N) R a--(6)$

Where

$\mathrm{n}=$ actual sunshine, hours 
$\mathrm{N}=$ maximum sunshine with respect to latitude and time of year, hours (obtained from table FAO 1977).

$\mathrm{Ra}=$ extra-terrestrial radiation with respect to latitude and time of the year mm/day (obtained from table FAO 1977).

$\mathrm{Ra}=$ solar radiation in equivalent evaporation, $\mathrm{mm} /$ day.

$A=$ reflectivity factor (obtained from table FAO 1977).

Rnl = f(T).f(ed).f(n/N)--- (7)

Where

$\mathrm{f}(\mathrm{T})$ = function of temperature against known mean air temperature (obtained from table FAO 1977)

Rns $=$ function of statured vapor pressure

(Obtained from table FAO 1977).

$\mathrm{F}(\mathrm{n} / \mathrm{N})=$ function of actual sunshine hours to maximum sunshine hours, obtained from table FAO (1977).

\section{Irrigation Requirement}

Following field water balance model was employed to compute the net irrigation requirement:

In = ETcrop $-(\mathbf{P e}+\mathrm{Ge}+\mathrm{Wb})---(8)$

Where

In = net irrigation requirement, $\mathrm{mm}$

ETcrop = crop water requirement, $\mathrm{mm}$

$\mathrm{Pe}=$ effective rainfall, $\mathrm{mm}$

$\mathrm{Ge}=$ ground contribution, $\mathrm{mm}$

$\mathrm{Wb}=$ stored soil water at the beginning of each period, $\mathrm{mm}$

\section{Result and Discussion}

\section{Identification of the project area command area}

A detailed survey of the project area command area was carries out. The information regarding the existing cropping pattern, size of the farms, area irrigated by canals, soil type, irrigation facilities, condition of canals, rainfall in the command area are taken into consideration. Calculations and estimation of the Potential Evap-transpiration Crop coefficient, Crop Water Requirement, Net Irrigation and Actual Project Supply Requirement of the canal were done. The calculation leads to conclusion that there is an urgent need for proper irrigation facility to get optimum crop production in improve the economic condition of farmers.

\section{Evaluation of the Canal Irrigation Project}

\section{Potential Evap-transpiration ETp}

The daily potential Evap-transpiration (2016-2017) estimated by modified Penman model for Allahabad is presented in fig Potential Evap-transpiration highly varies from July to December due to variations by temperature, relative humidity and radiations. The potential Evap-transpiration decreases from January up to first week of the March afterwards it tend to increase second week of March to the maximum value in the month of June to increase in evaporative demand. Inspire of high temperature the potential Evap-transpiration in July and August was considerably low as compared to March, April and May mainly due to cloudy weather conditions. High variation in potential Evap- transpiration was observed through the year.

\section{Crop Coefficient for the crops grown in the command area}

The Crop Coefficient for the paddy increased from July to the end of August due to increase in green index and thereafter it tends to decline due to considerable reduction in leaf area index. The maximum value of crop coefficient for paddy was observed to be 1.290. The Crop Coefficient for wheat increases considerably from November to the first week of January due to increase in green area index and there after it tend to decline mainly due to reduction in leaf index. The maximum value of crop for wheat was observed to be 0.874 . The Crop Coefficient for gram increases considerably from November to the second week of January due to increase in green area index and and thereafter it tend to decline mainly because of reduction in leaf index. The highest value of crop coefficient for gram was observed to be 1.167. The Crop Coefficient for potato grown in the command area of all eight minors is shown in Crop coefficient for potato increases considerably from November to the third week of January due to increase in green area index and thereafter it tend to decline mainly because of reduction in leaf index. The highest value of crop coefficient for gram was observed to be 1.563 .

\section{Crop Water Requirement}

The daily crop water requirement of paddy was highly varying during the crop-growing season due to variation in potential Evap-transpiration. At the beginning of crop growth period the crop water requirement was high due to high evaporative demand. The maximum value of crop water requirement was estimated to be $7.345 \mathrm{~mm} /$ day in the month of August. At the end of the crop growing season water requirement for paddy declines due to decrease in Evap-transpiration and crop coefficient. The daily crop water requirement of wheat grown in the command area was low during early crop growth period mainly low crop coefficient. The crop water requirement increases considerably in the mid of crop growing season from second week of January up to the first week of February. The maximum daily crop water requirement for the wheat was estimated to be $3.511 \mathrm{~mm} /$ day in the third week of January.

\section{Daily supply requirement and water supplied by canal}

The actual daily supply requirement and water supplied by Majhgawan minor for its command area during the crop growing 
is presented in The water supplied by the Majhgawan minor for its command area was 19, 732 cubic meters per day and was constant throughout the crop growing season while the actual daily supply requirement was highly varying. The variation in the actual water supply requirement was due to variation in evaporative demand. The maximum actual water supply requirement was estimated to be approximately 1, 48,134 cubic meters per day in the month of August. During the month of December the water requirement. There was no supply of water in the months of April, May and June. The study clearly shows that water supplied by Majhgawan minor for its command area was extremely low throughout the crop growing season except in the month of July when the supply was in excess.

The actual daily supply requirement and water supplied by Barguana minor for its command area during the crop growing season is presented in The water supplied by Barguana minor for its command area was 19536 cubic meters per day and was constant throughout the crop growing season while the actual daily supply requirement was highly varying. The variation in the actual water supply requirement was due to variation in evaporative demand. The maximum actual water supply requirement was estimated to be approximately 1, 48,134 cubic meters per day in the month of August. During the month of December the water requirement. There was no supply of water in the months of April, May and June. The study clearly shows that water supplied by Barguana minor for its command area was extremely low throughout the crop growing season except in the month of July when the supply was in excess.

The actual daily supply requirement and water supplied by Banoury minor for its command area during the crop growing is presented in. The water supplied by the Banoury minor for its command area was 5403 cubic meters per day and was constant throughout the crop growing season while the actual daily supply requirement was highly varying. The variation in the actual water supply requirement was due to variation in evaporative demand. The maximum actual water supply requirement was estimated to be approximately 1, 09,565 cubic meters per day in the month of August. During the month of December the water requirement. There was no supply of water in the months of April, May and June. The study clearly shows that water supplied by Banoury minor for its command area was extremely low throughout the crop growing season except in the month of July when the supply was in excess.

The actual daily supply requirement and water supplied by Baitibajhiya minor for its command area during the crop growing is presented in The water supplied by the Baitibajhiya minor for its command area was 2176 cubic meters per day and was constant throughout the crop growing season while the actual daily supply requirement was highly varying. The variation in the actual water supply requirement was due to variation in evaporative demand. The maximum actual water supply requirement was estimated to be approximately 63,380 cubic meters per day in the month of August. During the month of December the water requirement. There was no supply of water in the months of April, May and June. The study clearly shows that water supplied by Baitibajhiya minor for its command area was extremely low throughout the crop growing season except in the month of July when the supply was in excess.

The actual daily supply requirement and water supplied by Baraouli minor for its command area during the crop growing is presented in. The water supplied by the Baraouli minor for its command area was 5183 cubic meters per day and was constant throughout the crop growing season while the actual daily supply requirement was highly varying. The variation in the actual water supply requirement was due to variation in evaporative demand. The maximum actual water supply requirement was estimated to be approximately 94,334 cubic meters per day in the month of August. During the month of December the water requirement. There was no supply of water in the months of April, May and June. The study clearly shows that water supplied by Baraouli minor for its command area was extremely low throughout the crop growing season except in the month of July when the supply was in excess.

The actual daily supply requirement and water supplied by Purwa minor for its command area during the crop growing is presented in The water supplied by the Purwa minor for its command area was 18,534 cubic meters per day and was constant throughout the crop growing season while the actual daily supply requirement was highly varying. The variation in the actual water supply requirement was due to variation in evaporative demand. The maximum actual water supply requirement was estimated to be approximately 88,684 cubic meters per day in the month of August. During the month of December the water requirement. There was no supply of water in the months of April, May and June. The study clearly shows that water supplied by Purwa minor for its command area was extremely low throughout the crop growing season except in the month of July when the supply was in excess.

The actual daily supply requirement and water supplied by Tilakhwar minor for its command area during the crop growing is presented in The water supplied by the Tilakhwar minor for its command area was 13,423 cubic meters per day and was constant throughout the crop growing season while the actual daily supply requirement was highly varying. The variation in the actual water supply requirement was due to variation in evaporative demand. The maximum actual water supply.

\section{Conclusion}

a. The crop water requirement for different crops grown in the command area of the eight minors of Karchhana distributaries varies with evaporative demand and crop growth period. 
b. The actual daily supply requirement of different crops g grown in the command area of the eight minors of the Karchhana distributaries was too high as compared to the water supplied by the minors for their respective command areas.

c. During the Kharif crop growing seaso(July-October) the amount of water supplied by all eight minors was highly insufficient to meet the actual requirement for their respective command area.

d. During the Rabi crop growing season (NovemberMarch) the amount of water supplied by all eight minors was highly insufficient to meet the actual requirement for their respective command area.

e. During to summer season (April-June) there was no supply from canals. f. The results reveal that there should be some alternate source of water for the command area of all eight minors to meet the actual daily supply requirement.

\section{References}

1. Doorenbos J, Pruitt WO (1977) Guidelines for Predicting crop water requirements. FAO Irrigation and Drainage paper no 24 FAO, Rome, Italy.

2. Gupta A, Pandey KG (2009) Critical Appraisal of Canal irrigation Project -A case study of Belen Main Canal shiats, India.

3. Mishra AR (2001) Appraisal of canal irrigation project -A case study of six minors of Meja branch Canal. Shiats, India.

4. Upadhaya A, Sikka AK, Singh AK, Kumar J (2006) Performance Evaluation of Patna Main Canal Command . ICAR, India.

\section{Your next submission with Juniper Publishers} will reach you the below assets

- Quality Editorial service

- Swift Peer Review

- Reprints availability

- E-prints Service

- Manuscript Podcast for convenient understanding

- Global attainment for your research

- Manuscript accessibility in different formats ( Pdf, E-pub, Full Text, Audio)

- Unceasing customer service

Track the below URL for one-step submission https://juniperpublishers.com/online-submission.php 